\title{
Lymphadenopathies: An Annoyance or Not?
}

\author{
(D) Şule Gökçe, (D) Zafer Kurugöl, (1) Güldane Koturoğlu
}

Ege University Faculty of Medicine, Department of Pediatrics, İzmir, Turkey

\begin{abstract}
Aim: The aim of this study was to evaluate the cases hospitalized with lymphadenopathy in terms of demographic and clinical characteristics, lymph node involvement regions, infection markers and their diagnoses.

Materials and Methods: The medical records of 56 children with lymphadenopathy between 2014 and 2017 were reviewed retrospectively at Ege University, Children's Hospital, General Pediatrics Unit. Demographic characteristics, clinical findings and accompanying complaints of the cases were examined. Laboratory tests including complete blood count, sedimentation rates and other biochemical parameters were measured. Lymph nodes were assessed via ultrasonographic examination in terms of distribution, number, size and structure. Lymph node regions were described as anterior or posterior cervical, supraclavicular, submandibular, axillary, epitrochlear, inguinal or popliteal. Laboratory results, microbiological studies and histopathological examination results of the patients were evaluated.

Results: Among the 56 patients enrolled in the study, 31 (55.4\%) were male, 25 (44.6\%) were female and the median age was $3.7 \pm 7.1$ years. The most frequent involvement location of the enlarged lymph nodes was the cervical area. Others occurred in the axillary, inguinal or supraclavicular regions. The median results of the white blood cell, C-reactive protein and erythrocyte sedimentation rates were 13.670 $\pm 9760 / \mathrm{mm}^{3}, 1.9 \pm 5.4 \mathrm{mg} / \mathrm{dL}$ and $42 \pm 51 \mathrm{~mm} / \mathrm{h}$ respectively. Ultrasonographic evaluation showed that lymph nodes were diagnosed with reactive hyperplasia in $69.6 \%$, suppurative lymphadenopathy in $23.2 \%$ and suspected malignancy in $7.1 \%$. Most of the cases with lymphadenopathy resulted from a benign condition.

Conclusion: Lymphadenopathy is a common complaint of childhood, mostly benign. The etiology should be elucidated using full history, careful physical examination, follow-up, laboratory and imaging methods. A good physical examination and follow-up of the clinical features of the lymph node are more important than the laboratory and imaging methods. If there is no change in lymph node size in the follow-up, further studies should be performed.

Keywords: Lymphadenopathy, childhood, benign conditions
\end{abstract}

\section{Introduction}

Lymph nodes that are located in various parts of the body interconnected through lymphatic channels are the most important part of the immune system. The lymphatic system consists of approximately 600 lymph nodes. The lymphatic fluid, an ultra-filtered form of blood that is rich with lymphocytes, is free to circulate through ducts and is transported to the right lymphatic duct or thoracic duct. The lymphatic fluid is connected to the system via the right and left subclavian venules via these ducts. Knowing the location of the lymph node and the location of its drainage helps to clarify lymph node pathologies. The appropriate and timely inflammatory response when antigens enter the body mostly through the gastrointestinal and respiratory system leads to the production of antibodies and cytokines and $\mathrm{T}$ cell proliferation in lymph nodes. This inflammatory response enlarges the lymph nodes (1). Lymphadenopathy (LAP) usually describes all pathological conditions of the lymph nodes while lymphadenomegaly explains the swollen lymph node. Detected lymph nodes in two or more non-adjacent regions are described as "generalized LAP". Localized LAP refers to the involvement of only one lymph node region. LAP is a common clinical problem which can occur at any age and one

\section{Address for Correspondence}

Şule Gökçe MD, Ege University Faculty of Medicine, Department of Pediatrics, İmir, Turkey Phone: +90 5057820701 E-mail: sule.gokce@yahoo.com ORCID ID: orcid.org/0000-0003-3392-4990

Received: 18.03.2018 Accepted: 05.04.2018

${ }^{\circ}$ Copyright 2018 by Ege University Faculty of Medicine, Department of Pediatrics and Ege Children's Foundation The Journal of Pediatric Research, published by Galenos Publishing House. 
of the leading causes of general outpatient admissions $(2,3)$. Due to the fact that LAP can be the first finding of malignant diseases especially in childhood, it is a cause of serious anxiety in families. Palpable supraclavicular, iliac, popliteal, epitrochlear nodes greater than $0.5 \mathrm{~cm}$, inguinal nodes larger than $1.5 \mathrm{~cm}$, and cervical/axiller nodes larger than $1 \mathrm{~cm}$ are considered abnormal (4). The most common causes of lymphadenopathies are infections (5). Other causes including autoimmune diseases, histiocytosis, malignant diseases, lipid storage diseases, drug reactions and granulomatous diseases might be related to the enlargement of the lymph nodes (6). Since possible malignant diseases may be a finding; detailed physical examination of the patient, careful examination of the lymph nodes regarding changes in size, consistency and settlement are absolutely necessary. In the current study, we aimed to evaluate retrospectively the demographic and clinical data, lymph node involvement, infection markers and diagnoses of the patients hospitalized with LAP.

\section{Materials and Methods}

The medical records of 56 children with lymphadenopathy between 2014 and 2017 were reviewed retrospectively at Ege University, Children's Hospital, General Pediatrics Unit. Demographic characteristics, clinical findings and accompanying complaints, and also the laboratory markers such as white blood cells (WBC), sedimentation rate and several biochemical investigations of the cases were examined on admission. Ultrasonographic examination of the lymph nodes assessed their distribution, number, size and structure. Lymph node regions were described as anterior or posterior cervical, supraclavicular, submandibular, axillary, epitrochlear, inguinal or popliteal. Palpable supraclavicular, iliac, popliteal, epitrochlear nodes greater than $0.5 \mathrm{~cm}$, inguinal nodes larger than $1.5 \mathrm{~cm}$ and cervical/axiller nodes larger than $1 \mathrm{~cm}$ are considered abnormal. The laboratory results, viral serologic studies and histopathological examination results of the patients were evaluated. For the patients who, as a result of their physical examination and laboratory tests, were thought to be infected, appropriate antibiotics were administered and they were recalled for check-up. Histopathologic examination was performed on patients whose lymph node size did not regress by the end of four or more weeks, and in whom there was no indication of an infectious disease.

\section{Statistical Analysis}

The data were analyzed using the statistical package for social sciences (SPSS) (version 17). All data were described as means and standard deviations or medians and ranges. Categorical variables were expressed by percentages. Pearson correlation analysis was used for the parameters. A p value $<0.05$ was statistically significant.

\section{Results}

Among the 56 patients enrolled in the study, 31 (55.4\%) were male, 25 (44.6\%) were female and the median age was 3.7 \pm 7.1 years. Table I shows the demographic and other clinical features of our cases. Overall, 23 (41.1\%) cases with swelling on the neck, 3 cases (5.4\%) on inguinal and 2 (3.6\%) cases in the axilla region were admitted to the hospital. Associated symptoms including sore throat, fever, cough and pain in the lymph node were observed. Ten patients (17.9\%) had hepatomegaly, 10 (17.9\%) splenomegaly and 5 $(8.9 \%)$ hepatosplenomegaly on physical examination. When the lymph nodes were classified according to size as $<1,1-3$, and $>3 \mathrm{~cm}, 15$ (26.8\%) patients had lymph nodes of $1-3 \mathrm{~cm}$ and $38(67.9 \%)$ had lymph nodes of $>3 \mathrm{~cm}$. There was no history of any drugs that may have caused the enlargement of the lymph node in the patients. In the acute LAP group, $42(89.3 \%)$ patients of the 47 had benign etiologies and 5 $(10.6 \%)$ had been diagnosed with malignancies. Of the 9 patients presenting with chronic LAP, only 2 (22.2\%) had malign etiologies (one had Hodgkin lymphoma and the other non-Hodgkin lymphoma), whereas 6 had benign lesions (4 of them had non-specific reactive hyperplasia and two patients were diagnosed with Mycobacterium tuberculosis). Inflammatory markers were examined in all the patients. The median of the WBC, C-reactive protein and erythrocyte sedimentation rate (ESR) were 13.670 \pm 9760 / $\mathrm{mm}^{3}, 1.9 \pm 5.4 \mathrm{mg} / \mathrm{dL}$ and $42 \pm 51 \mathrm{~mm} / \mathrm{h}$ respectively. The laboratory features are summarized in Table II. Positive Epstein-Barr virus immunoglobulin $\mathrm{M}$ (IgM) was detected in $6(10.7 \%)$ of the patients, and in $1(1.8 \%)$ cytomegalovirus IgM was seen. Viral pathogens were not found in the other patients. The median of lactate dehydrogenase was $244 \pm 109 \mathrm{U} / \mathrm{L}$ (normal range: 142-297). Ultrasonographic examination was performed on 50 (89.3\%) of the patients and it was found that $39(69.6 \%)$ of the patients had reactive features and that $4(7.1 \%)$ had possible malignant lymph nodes. Neck tomography in 22 (39.3\%) of our patients showed abscess formation in the lymph node in 12 (54.6\%) of these. Lymphadenitis accompanied by abscess was surgically drained and necessary microbiological samples were sent to the microbiology laboratory. The most common microorganism was Staphylococcus aureus. Mycobacteriological examination of three patients revealed M. tuberculosis, and mycological examination revealed fungal infection in two. Two other patients had a parasitic infection. Histopathologic examination was performed on 26 patients. Sixteen of all the patients were diagnosed with reactive hyperplasia, 4 with Hodgkin lymphoma, 3 with nonHodgkin lymphoma, one with langerhans cell histiocytosis, one with dermatopathic lymphadenitis and one patient was diagnosed with Kikuchi Fujimato disease (Table II). 


\begin{tabular}{|c|c|}
\hline Demographic features & \\
\hline Age [median (IQR)]/years & $3.7(7.1)$ \\
\hline $\begin{array}{r}\text { Gender, } \mathbf{n}(\mathbf{\%}) \\
\text { Male } \\
\text { Female }\end{array}$ & $\begin{array}{l}31(55.4) \\
25(44.6)\end{array}$ \\
\hline $\begin{array}{l}\text { Causes for admission, } \mathbf{n}(\%) \\
\text { Neck swelling } \\
\text { Neck swelling + fever } \\
\text { Throat pain } \\
\text { Axillary swelling } \\
\text { Inguinal swelling } \\
\text { Supraclavicular swelling } \\
\text { Supraclavicular swelling + fever } \\
\text { Neck + inguinal swelling } \\
\text { Neck + axillary swelling } \\
\text { Neck + supraclavicular swelling } \\
\text { Axillary + inguinal swelling }\end{array}$ & $\begin{array}{l}25(44.6) \\
18(32.1) \\
1(1.8) \\
3(5.4) \\
2(3.6) \\
- \\
2(3.6) \\
- \\
4(7.1) \\
- \\
1(1.8)\end{array}$ \\
\hline Duration [median (IQR)]/days & $7(11)$ \\
\hline $\begin{array}{r}\text { Duration, } \mathbf{n}(\%) \\
\text { Acute } \\
\text { Chronic }\end{array}$ & $\begin{array}{l}47(83.9) \\
9(16.1)\end{array}$ \\
\hline $\begin{array}{c}\text { Infection history before admission, } \mathbf{n}(\%) \\
\text { Yes } \\
\text { No } \\
\end{array}$ & $\begin{array}{l}35(62.5) \\
21(37.5)\end{array}$ \\
\hline $\begin{array}{l}\text { Antibiotic use before admission, } \mathbf{n}(\%) \\
\text { Yes } \\
\text { No }\end{array}$ & $\begin{array}{l}29(51.8) \\
27(48.2)\end{array}$ \\
\hline $\begin{array}{l}\text { Associated symptoms, } \mathbf{n}(\%) \\
\text { Fever } \\
\text { Sore throat } \\
\text { Sore throat and fever } \\
\text { Rash } \\
\text { Weight loss } \\
\text { Night sweating } \\
\text { Fever, weight loss and night sweating } \\
\text { Cough and fever } \\
\text { Rash and fever } \\
\text { Arthralgia } \\
\text { Arthralgia and fever } \\
\text { Thrombocytopenia } \\
\text { Earache } \\
\text { Cough } \\
\text { Not associated symptoms }\end{array}$ & $\begin{array}{l}19(33.9) \\
1(1.8) \\
1(1.8) \\
2(3.6) \\
2(3.6) \\
1(1.8) \\
1(1.8) \\
2(3.6) \\
2(3.6) \\
1(1.8) \\
1(1.8) \\
1(1.8) \\
1(1.8) \\
1(1.8) \\
20(35.7) \\
\end{array}$ \\
\hline $\begin{array}{c}\text { Extension, } \mathbf{n}(\%) \\
\text { Ceneralized } \\
\text { Local }\end{array}$ & $\begin{array}{l}12(21.4) \\
44(78.6)\end{array}$ \\
\hline $\begin{array}{l}\text { Site distribution of lymph nodes, } \mathbf{n}(\%) \\
\text { Cervical } \\
\text { Submandibular } \\
\text { Cervical + submandibular } \\
\text { Cervical + axillary } \\
\text { Cervical + inguinal } \\
\text { Inguinal } \\
\text { Axillary } \\
\text { Cervical + inguinal + submandibular } \\
\text { Cervical + supraklavikular } \\
\text { Axillary + inguinal + submandibular } \\
\text { Cervical + axillary + inguinal preauriküler }\end{array}$ & $\begin{array}{l}23(41.1) \\
7(12.5) \\
7(12.5) \\
5(8.9) \\
3(5.4) \\
3(5.4) \\
2(3.6) \\
1(1.8) \\
1(1.8) \\
1(1.8) \\
1(1.8)\end{array}$ \\
\hline
\end{tabular}

\begin{tabular}{|c|l|}
\hline Table I. Continued & \\
\hline Size, $\mathbf{n}(\%)$ & \\
$<1 \mathrm{~cm}$ & $2(5.4)$ \\
$1-3 \mathrm{~cm}$ & $15(26.8)$ \\
$>3 \mathrm{~cm}$ & $38(67.9)$ \\
\hline $\begin{array}{c}\text { Structure of the lymph node, } \mathbf{n}(\%) \\
\text { Soft }\end{array}$ & $32(57.1)$ \\
Fixed and stiffed & $23(41.1)$ \\
Inflamed appearance & $1(1.8)$ \\
\hline $\begin{array}{l}\text { Other organ involvement on physical } \\
\text { examination, } \mathbf{n} \text { (\%) }\end{array}$ & \\
Hepatomegaly & $10(17.9)$ \\
Splenomegaly & $10(17.9)$ \\
Hepatosplenomegaly & $5(8.9)$ \\
\hline
\end{tabular}

IQR: Interquartile range

Table II. Laboratory, radiologic and histopathological characteristics of the patients $(n=56)$

\begin{tabular}{|c|c|}
\hline $\begin{array}{l}\text { Biochemical analyses } \\
\text { Peripheral blood smear, } \mathbf{n}(\%) \\
\text { Normal } \\
\text { Atypical lymphocytes } \\
\text { Blasts } \\
\text { WBC [median (IQR)]/mm } \\
\text { CRP [median (IQR)]/mg/dL } \\
\text { ESR [median (IQR)]/mm/h } \\
\text { LDH [median (IQR)]/U/L } \\
\text { UA (mean } \pm \text { SD)/mg/dL }\end{array}$ & $\begin{array}{l}49(87.5) \\
7(12.5) \\
- \\
13.670(9760) \\
1.9(5.4) \\
42(51) \\
244 \pm 109 \\
3.6 \pm 1.2 \\
\end{array}$ \\
\hline $\begin{array}{l}\text { Chest X-ray, } \mathbf{n}(\%) \\
\text { Normal } \\
\text { Mediastinal LAP }\end{array}$ & $\begin{array}{l}53(94.6) \\
3(5.4)\end{array}$ \\
\hline $\begin{array}{l}\text { Radiology } \\
\text { Lymph node USG, } \mathbf{n}(\%) \\
\text { Reactive lymphadenitis } \\
\text { Suspected malignancy } \\
\text { Suppurative } \\
\text { Abdominal USC, } \mathbf{n}(\%) \\
\text { Normal } \\
\text { Organomegaly } \\
\text { Abdominal lymph node } \\
\text { Organomegaly and abdominal lymph node } \\
\text { *Neck tomography, } \mathbf{n}(\%) \\
\text { Abscess } \\
\text { Benign findings } \\
\text { Malign findings }\end{array}$ & \begin{tabular}{|l|}
$39(69.6)$ \\
$4(7.1)$ \\
$13(23.2)$ \\
$44(78.6)$ \\
$4(7.1)$ \\
$5(8.9)$ \\
$3(5.4)$ \\
\\
$12(54.6)$ \\
$5(22.7)$ \\
$5(22.7)$ \\
\end{tabular} \\
\hline $\begin{array}{l}\text { Microbiological investigations, } \mathbf{n}(\%) \\
\text { EBV } \\
\text { CMV } \\
\text { Staphylococcus aureus } \\
\text { Streptococcus pneumoniae } \\
\text { Mycobacterium tuberculosis } \\
\text { Parasitic infection } \\
\text { Fungal infection }\end{array}$ & $\begin{array}{l}6(10.7) \\
1(1.8) \\
8(14.3) \\
3(5.4) \\
3(5.4) \\
2(3.6) \\
2(3.6) \\
\end{array}$ \\
\hline $\begin{array}{l}\text { **Histopathological diagnosis, } \mathbf{n}(\%) \\
\text { Reactive hyperplasia } \\
\text { Hodgkin's lymphoma } \\
\text { Non-Hodgkin's lymphoma } \\
\text { Dermatopathic lymphadenopathy } \\
\text { Kikuchi-Fujimoto disease } \\
\text { Langerhans cell histiocytosis }\end{array}$ & $\begin{array}{l}4(15.4) \\
3(11.6) \\
16(61.6) \\
1(3.8) \\
1(3.8) \\
1(3.8)\end{array}$ \\
\hline
\end{tabular}

CMV: Cytomegalovirus, EBV: Epstein-Barr virus, CRP: C-reactive protein, ESR: Erythrocyte sedimentation rate, IQR: Interquartile range, LDH: Lactate dehydrogenase, SD: Standard deviation, UA: Uric acid, WBC: White blood cell ${ }^{*}(\mathrm{n}=22),{ }^{* *}(\mathrm{n}=26)$ 


\section{Discussion}

LAP is a common clinical scenario in childhood and most of the cases result from a benign condition. Although it can be the manifestation of a serious systemic disease or malignancy, its percentage is quite low. Detailed history, appropriate and timely evaluation of physical examination and laboratory findings provide a guide for the differential diagnosis in the evaluation of the LAP. Qualified-close clinical follow-up and the determination of high/low risk factors for malignancy can prevent unnecessary investigation in the diagnosis of enlarged lymph nodes. Growth in lymph nodes usually occurs during the first two weeks of antigenic stimulation and is expected to decrease within 4-6 weeks after the end of the stimulation (3). In the absence of regression, the patients should be re-evaluated via histopathological examination. In our study, similar to the studies in the literature, most of the cases seemed to be the result of benign causes $(87.5 \%)$, and only 7 patients were diagnosed with a malignant disease. Totally, a specific etiology was found in 35 (62.5\%) of the patients. The overall percentage of malignant disorders was $12.5 \%$ in our study. A study from our country conducted by Oguz et al. (7) reported that a specific etiology was found in $58 \%$ of the patients, and malignant disease was seen in $24.3 \%$. In the study of Moore et al. (8) a malignant cause was found in $11.6 \%$ of the children who had undergone lymph node biopsy. In another study in which 185 patients were evaluated, it was stated that benign pathologies were seen in $33.5 \%$ of the patients, and $64.5 \%$ of them had a swollen lymph node that was characterized by reactive features (9). The duration of lymphadenopathies is significant in determining their cause. If the complaints go on for less than four weeks, it is considered an acute lymph node enlargement; complaints continuing longer than 4 weeks are described as chronic LAP (10). It is reported that the duration of LAP is significantly longer for malignant disorders and usually occurs as chronic LAP (11). In this study, with the exception of 5 patients diagnosed with malignant disorders, benign causes were found in most of the cases of hospitalized LAP to be characterized with a duration less than 4 weeks. Oguz et al. (7) evaluated 457 patients, 218 of whom had acute LAP and $98.2 \%$ of them were diagnosed with benign diseases. Two hundred thirty nine patients presented as chronic LAP, and 132 (55.2\%) of these 239 patients had benign etiologies, whereas 107 had malignancies (44.8\%) (8). It is important to be careful about malignancy and to perform histopathologic examination of those lymph nodes that persist for more than four weeks and do not regress in size. Localized lymph node enlargement usually occurs in acute diseases such as localized infections or tooth decay. Firstly, patients with localized LAP should be examined thoroughly and screened for infections (12). Cervical lymph nodes are often enlarged due to a variety of infections of the head and neck or due to some systemic infections such as Epstein-Barr virus, cytomegalovirus infection or toxoplasmosis (13). It is emphasized that none of the lymph nodes detected at the supraclavicular region were benign and immediate biopsy was recommended (7). The supraclavicular area is generally related to malignancy in all ages. Another study reported that $4.8 \%$ of 185 patients had a swollen lymph node at the supraclavicular region and these were mostly diagnosed with non-Hodgkin lymphoma (9). In our study, a swollen lymph node was detected at the supraclavicular region in $2(3.6 \%)$ patients and one of them was classic Hodgkin lymphoma and the other was Kikuchi-Fujimoto disease. Generalized LAP is usually a sign of an underlying systemic disease or Epstein-Barr virus, HIV, lymphoma or autoimmune disorders. The most common malignant disease in childhood is non-Hodgkin's lymphoma, causing extensive lymph node enlargement (14-16). In our study, out of a total of 12 patients with generalized lymph node, one of them was diagnosed with B-cell lymphoma and the others were diagnosed with benign conditions. Local or generalized LAP is not an indication of malignancy. The size of the lymph node is an important factor in order to distinguish the etiology. In general, a size of more than $2 \mathrm{~cm}$ is the upper limit for a malignancy or a granulomatous disease (17). In a study by Soldes et al., (18) predictive parameters for malignancy were reported as lymph nodes bigger than 1 $\mathrm{cm}$ in size. Oguz et al. (7) found that $85.6 \%$ of the patients with lymph nodes larger than $3 \mathrm{~cm}$ had malign diseases. In the same study, it was said that small lymph nodes that were under $1 \mathrm{~cm}$ were benign and that those between 1-3 $\mathrm{cm}$ could not indicate a clear evaluation concerning the disease. Although lymph node size might give an idea about diseases, there is no clear limiting value in the malignantbenign distinction (12). There was no correlation between malignancy and size of the lymph node in our study $(p>0.05)$. To rule out malignancy, excisional biopsy was applied to 26 (46.4\%) of our cases. Histopathologically, the most frequent malignancies were Hodgkin and non-Hodgkin lymphoma. Despite biopsy, a specific etiology could not be found in some cases hospitalized with LAP (61.6\%). Similar to our study, Oguz et al. (7) could not find any specific cause with biopsy in $46.2 \%$ patients and no specific disease was detected in them.

\section{Conclusion}

Lymph node enlargements are a common condition in childhood which can obsess the families and physicians in some cases. They are usually associated with infections. A detailed history, complete physical examination and also the size and duration of the complaints are very important in determining the cause. Lymphadenopathies that are at the supraclavicular region, larger than $2 \mathrm{~cm}$ diameters, going on longer than 4 weeks and not responding to non-specific antibiotic treatment should be suspected in terms of malignancy. 


\section{Ethics}

Ethics Committee Approval: Retrospective study. Informed Consent: Retrospective study.

Peer-review: External and internal peer-reviewed.

\section{Authorship Contributions}

Concept: Ş.G., Z.K., G.K., Design: Ş.G., Data Collection: S..G., Analysis and Interpretation: Z.K., Literature Search: Z.K., G.A., Writing: Ş.G.

Conflict of Interest: No conflict of interest was declared by the authors.

Financial Disclosure: The authors declared that this study received no financial support.

\section{References}

1. Olgun N. Çocukluk çağı lenf bezleri. İrken G, Özkan H, Aydın A, editörler. Pediatri Kliniğe Giriş, 1. baskı, DEU Rektörlük Matbaası, İzmir, 2001.p.71-93.

2. Kelly CS, Kelly RE. Lymphadenopathy in children. Pediatr Clin North Am 1998;45:875-88.

3. Twist C), Link MP. Assessment of lymphadenopathy in children. Pediatr Clin North Am 2002;49:1009-25.

4. Ferrer R. Lymphadenopathy: differential diagnosis and evaluation. Am Fam Physician 1998;58:1313-20.

5. Thorell EA, Chesney P. Cervical lymphadenitis and neck infections. In: Long S, Pickering L Prober C (eds). Principles and practice of pediatric infectious diseases. 2nd ed. New York: Churchill Livingstone, 2008:143.

6. Friedmann AM. Evaluation and management of lymphadenopathy in children. Pediatr Rev 2008;29:53-60.
7. Oguz A, Karadeniz C, Temel EA, Çağlar C Elvan, Okur V. Evaluation of peripheral lymphadenopathy in children. Pediatric Hematology and Oncology 2006;23:549-61.

8. Moore SW, Schneider JW, Schaaf HS. Diagnostic aspects of cervical lymphadenopathy in children in the developing world: a study of 1,877 surgical specimens. Pediatr Surg Int 2003;19:240-4.

9. Özkan EA, Göret CC, Özdemir ZT, et al. Evaluation of peripheral lymphadenopathy with excisional biopsy: six-year experience. Int J Clin Exp Pathol 2015;8:15234-9.

10. Kumral A, Olgun N, Uysal KM, Corapcioğlu F, Oren H, Sarialioğlu F. Assessment of peripheral lymphadenopathies: experience at a pediatric hematology-oncology department in Turkey. Pediatr Hematol Oncol 2002;19:211-8.

11. Pangalis GA, Vassilakopoulos TP, Boussiotis VA, Fessas P. Clinical approach to lymphadenopathy. Semin Oncol 1993;20:570-82.

12. Mohseni S, Shojaiefard A, Khorgami Z, Alinejad S, Ghorbani A, Ghafouri A. Peripheral lymphadenopathy: approach and diagnostic tools. Iran J Med Sci 2014;39(2 Suppl):158-70.

13. Habermann TM, Steensma DP. Lymphadenopathy. Mayo Clin Proc 2000;75:723-32.

14. Karnath BM. Approach to the patient with lymphadenopathy. Hospital physician 2005;41:29-33.

15. Gaines $H$, von Sydow M, Pehrson PO, Lundbegh P. Clinical picture of primary HIV infection presenting as a glandular-feverlike illness. BMJ 1988;297:1363-8.

16. Kojima M, Matsuda H, lijima M, Yoshida K, Masawa N, Nakamura S. Reactive hyperplasia with giant follicles in lymph node lesions from systemic lupus erythematosus patients. Report of three cases. APMIS 2005;113:558-63.

17. Slap GB, Brooks JS, Schwartz JS. When to perform biopsies of enlarged peripheral lymph nodes in young patients. JAMA 1984;252:1321-6.

18. Soldes OS, Younger JG, Hirschl RB. Predictors of malignancy in childhood peripheral lymphadenopathy. I Pediatr Surg 1999;34:1447-52. 